have an important place. But young people should be induced to form those sentimental attachments that will lead to racial betterment rather than deterioration.

The importance of environment in providing the fertile soil in which the seeds of hereditary promise may grow, should not be minimized. But the prevalence in democracies like ours of the fallacious dogma of human equality makes it imperative to emphasize the fundamental importance of heredity.

\section{SUMMARY}

It is impossible to say to what extent the views of these students will affect their future conduct with reference to matrimony, but undoubtedly there will be an effect.

For the most part the attitude of the students in the University of Missis- sippi is morally and eugenically good. Almost all the men and about threequarters of the women intend to marry, if circumstances permit. The average size of family preferred is four children. This number is sufficient to replace this group in the next generation. The relative rating of those traits which are usually considered in choosing a husband or wife are morally, and for the most part eugenically, sound. Doubtless the questionnaires were filled out by the better class of students, since one would naturally suppose that such students would be most likely to take an interest in an investigation of this kind. If this assumption is correct, these findings are particularly gratifying. As far as can be determined the changes in attitude toward matrimony have been mostly for the better, showing that the moral atmosphere of the University is good.

\title{
A German Statement of Eugenics
}

Grundriss der Menschlichen ErBLICHKEITSLEHRE UND RASSENHYgiene, Band II : Menschliche AusLESE UND Rassenhygiene, von Dr. Fritz Lenz, privatdozent für hygiene an der Universität München, pp. 251, preis des I u. II Bandes in 1 Band gebunden, \$2.60; München, J. F. Lehmanns Verlag, 1921.

One of the encouraging facts about the science of eugenics is that it has now become somewhat stabilized. Take the presentation of the leaders of the movement in the United States, England,
France, and Germany, for instance, and there will be found to be remarkably little divergence among them, on fundamental questions of eugenic policy. The present book, which is quite the best I have seen from the Continent, gives a sound and conservative account of natural and artificial selection in man, of "social race hygiene" and of "private race hygiene." Although it is not well documented, it will be of great interest to all in the United States who are concerned with the eugenics movement. In Germany it has already gone into a second edition.-P.P.

\section{Biology and Religion}

The Direction of Human EvoluTION, by Edwin Grant Conklin, professor of biology in Princeton University. Pp. 247, price $\$ 2.50$. New York, Charles Scribner's Sons, 1921.

This series of lectures, delivered on a foundation calling for discussion of the mutual bearings of science and religion, will give the reader who has little acquaintance with biology a good idea of some of the broader fundamental concepts. Its widespread perusal should help to make for a better understanding of the application of the doctrine of evolution to many important problems of human philosophy and politics.-P.P. 